\title{
Effects of bacterial direct-fed microbials on ruminal characteristics, methane emission, and milk fatty acid composition in cows fed high- or low-starch diets
}

\author{
C. Philippeau, ${ }^{*} \dagger^{1}$ A. Lettat, ${ }^{*} \ddagger^{1}$ C. Martin,${ }^{* 2}$ M. Silberberg, ${ }^{*}$ D. P. Morgavi, ${ }^{*}$ A. Ferlay, ${ }^{*}$ C. Berger, $\S$ \\ and $P$. Nozière* \\ *UMR1213 Herbivores, INRA, VetAgro Sup, Clermont Université, Université de Lyon, F-63122 Saint-Genès-Champanelle, France \\ †AgroSup Dijon, F-21079 Dijon Cedex, France \\ ‡Danisco France SAS, F-86220 Dangé Saint Romain, France \\ $\S$ Danisco France SAS, F-75017 Paris, France
}

\section{ABSTRACT}

This study investigated the effects of bacterial directfed microbials (DFM) on ruminal fermentation and microbial characteristics, methane $\left(\mathrm{CH}_{4}\right)$ emission, diet digestibility, and milk fatty acid (FA) composition in dairy cows fed diets formulated to induce different ruminal volatile fatty acid (VFA) profiles. Eight ruminally cannulated dairy cows were divided into 2 groups based on parity, days in milk, milk production, and body weight. Cows in each group were fed either a high-starch $(38 \%, \mathrm{HS})$ or a low-starch $(2 \%, \mathrm{LS})$ diet in a 55:45 forage-to-concentrate ratio on a dry matter (DM) basis. For each diet, cows were randomly assigned to 1 of 4 treatments in a Latin square design of (1) control (CON); (2) Propionibacterium P63 (P63); (3) P63 plus Lactobacillus plantarum 115 (P63+Lp); (4) P63 plus Lactobacillus rhamnosus 32 (P63+Lr). Strains of DFM were administered at $10^{10} \mathrm{cfu} / \mathrm{d}$. Methane emission (using the sulfur hexafluoride tracer technique), total-tract digestibility, dry matter intake, and milk production and composition were quantified in wk 3. Ruminal fermentation and microbial characteristics were measured in wk 4. Data were analyzed using the mixed procedure of SAS (SAS Institute Inc., Cary, NC). The 2 diets induced different ruminal VFA profiles, with a greater proportion of propionate at the expense of acetate and butyrate for the HS diet. Greater concentrations of total bacteria and selected bacterial species of methanogenic Archaea were reported for the HS diet, whereas the protozoa concentration in HS decreased. For both diets, bacterial DFM supplementation raised ruminal $\mathrm{pH}(+0.18 \mathrm{pH}$ units, on average $)$

Received June 27, 2016.

Accepted December 14, 2016.

${ }^{1}$ These authors contributed equally to this work.

${ }^{2}$ Corresponding author: cecile.martin@inra.fr compared with CON. Irrespective of diet, P63+Lp and $\mathrm{P} 63+\mathrm{Lr}$ increased ruminal cellulase activity (3.8-fold, on average) compared with CON, but this effect was not associated with variations in ruminal microbial numbers. Irrespective of diet, no effect of bacterial DFM on ruminal VFA was observed. For the LS diet, supplementing cows with $\mathrm{P} 63+\mathrm{Lr}$ tended to decrease $\mathrm{CH}_{4}$ emission (26.5\%, on average, when expressed per kilogram of milk or $4 \%$ fat-corrected milk). Only P63 supplementation to cows fed the HS diet affected the concentration of some milk FA, such as cis isomers of 18:1 and intermediates of ruminal biohydrogenation of polyunsaturated FA. Overall, bacterial DFM could be useful to stabilize ruminal $\mathrm{pH}$. Their effects on $\mathrm{CH}_{4}$ production mitigation and milk FA profile depended on DFM strain and diet and should be confirmed under a greater variation of dietary conditions.

Key words: bacterial direct-fed microbial, ruminal fermentation, methane, dairy milk fatty acid

\section{INTRODUCTION}

Direct-fed microbials (DFM) are commonly used in ruminant nutrition to stabilize ruminal fermentation in high-producing cattle. The yeast Saccharomyces cerevisiae is one of the most prevalent DFM used and has proven particularly effective when the digestive microbiota is challenged, for example, during feed transition or when diets are rich in highly fermentable carbohydrates (Chaucheyras-Durand et al., 2008; Desnoyers et al., 2009; McAllister et al., 2011).

In comparison with yeasts, bacterial DFM have received less attention even though many potential bacterial DFM are naturally present in the rumen. In a meta-analysis, Lettat et al. (2012a) reported a moderate effect of these bacterial DFM on ruminal fermentation and microbial characteristics in beef cattle and dairy cows. However, few studies have been published and they show great variability depending on bacterial 
DFM (species, strain, dose) and experimental conditions (diet, physiological state, and ruminant species).

By their ability to modulate ruminal fermentations, bacterial DFM have been proposed as potential enteric methane $\left(\mathrm{CH}_{4}\right)$ mitigation additives for ruminants (Jeyanathan et al., 2014). Among the bacterial DFM studied in the literature, some strains of propionibacteria have been shown to modulate $\mathrm{CH}_{4}$ emission in vitro (Alazzeh et al., 2012; Meale et al., 2014; Jeyanathan et al., 2016). Controversial results were reported in vivo. Supplementing beef cattle with Propionibacterium acidipropionici (P169 or P54) or Propionibacterium jensenii $\mathrm{P} 54$ induced a decrease in $\mathrm{CH}_{4}$ emission (on average, $-13 \% \mathrm{CH}_{4}$ expressed per $\mathrm{kg}$ of DMI) when they were fed a high-forage diet, whereas no effect of these strains was reported in beef cattle fed diets rich in corn grain (Vyas et al., 2014a,b). In sheep fed a hay-based diet (70:30 forage:concentrate on a DM basis) supplemented with Propionibacterium freudenreichii 53-W, an increase was found in $\mathrm{CH}_{4}$ emission per kilogram of DMI (16\%; Jeyanathan et al., 2016). Moreover, in vitro cultures of bacterial DFM with single fatty acids (FA) showed that propionibacteria may be proposed as modifiers of milk FA composition (Hennessy et al., 2012). However, in a rumen simulation technique, Propionibacterium freudenreichii had limited effect on biohydrogenation of PUFA (Meale et al., 2014).

Bacterial DFM supplementation consisting of the association of bacteria able to utilize lactate in the rumen with lactate-producing bacteria seemed an interesting way to alter rumen characteristics. Previous research showed that Propionibacterium P63 plus Lactobacillus plantarum $(\mathbf{L p}) 115$ or Lactobacillus rhamnosus $(\mathbf{L r}) 32$ DFM increased ruminal $\mathrm{pH}$ and modified ruminal fermentation in sheep with induced SARA (Lettat et al., 2012b). However, those authors reported that ruminal VFA profile was only modified in sheep fed a corn diet supplemented by Propionibacterium P63 plus Lactobacillus plantarum 115 DFM. Based on these previous results, we hypothesized that the effectiveness of these bacterial DFM associations on ruminal characteristics, $\mathrm{CH}_{4}$ emission, and milk FA composition would depend on the ruminal VFA profile. The aim of the present study was to evaluate effects of Propionibacterium P63 and Lactobacillus (Lp or Lr) DFM on ruminal fermentation and microbial characteristics, $\mathrm{CH}_{4}$ emission, and milk FA composition in dairy cows fed diets inducing different ruminal VFA profiles.

\section{MATERIALS AND METHODS}

The experiment was conducted at the animal experimental facilities of INRA Theix (Saint-Genès-Cham- panelle, France). Procedures on animals were in accordance with the guidelines for animal research of the French Ministry of Agriculture and all other applicable national and European guidelines and regulations for experimentation with animals (http://www2.vet-lyon. fr/ens/expa/acc_regl.html). The experiment was approved by the Auvergne regional ethics committee for animal experimentation (approval number CE20-09).

\section{Animals, Diets, and Experimental Procedure}

Eight lactating Holstein cows (including 2 primiparous) fitted with ruminal cannulas were divided at the beginning of experiment into 2 groups of 4 animals, conducted in parallel in a $4 \times 4$ Latin square design. Groups were balanced on their parity (mean \pm SD) $(2.3$ \pm 1.0 and $2.8 \pm 1.5)$, DIM $(76 \pm 19$ and $67 \pm 22 \mathrm{~d})$, milk production $(27 \pm 3$ and $28 \pm 6 \mathrm{~kg} / \mathrm{d})$, and $\mathrm{BW}$ (587 \pm 20 and $596 \pm 43 \mathrm{~kg}$ ), respectively.

Each group was fed (on a DM basis; Table 1) either a high-starch diet (HS; 38\%) or a low-starch diet (LS; $2 \%$ ) in a $55: 45$ forage:concentrate ratio to promote different ruminal VFA profiles. In addition, $0.25 \mathrm{~kg} / \mathrm{d}$ of a commercial mineral-vitamin premix was added to both diets. Both diets had similar contents of net energy and protein digested in the small intestine (Table 1) and were formulated to cover the INRA energy and protein requirements for maintenance and lactation of dairy cows (INRA, 2007). Animals were fed twice daily, $65 \%$ at $0900 \mathrm{~h}$ and $35 \%$ at $1600 \mathrm{~h}$. For 2 wk before the beginning of the experiment, cows were fed these diets ad libitum and then the feed offering during the trial was reduced to $90 \%$ of the ad libitum intake. Both diets were readjusted in each experimental period according to the forage:concentrate ratio and assuming a monthly decrease in milk production of $10 \%$. In addition, diets were free of antibiotics, chemical buffers, and yeast to avoid confusing effects with DFM.

Within each group, cows were randomly assigned to 4 treatments in a $4 \times 4$ Latin square design. Each experimental period lasted $4 \mathrm{wk}$ with measurements performed in the last $2 \mathrm{wk}$ (wk 3 and 4). The treatments were (1) control without bacterial DFM (CON) or supplemented with (2) Propionibacterium P63 (P63), (3) P63 plus Lactobacillus plantarum $115(\mathbf{P} 63+\mathbf{L p})$, or (4) P63 plus Lactobacillus rhamnosus 32 (P63+Lr). Bacterial DFM were mixed with a small portion of concentrate (sampled from their diet) and offered once daily before the morning feeding. Cows on the DFM treatments received $10^{10} \mathrm{cfu} / \mathrm{d}$ of each strain, whereas control cows received only carrier (lactose). The DFM were prepared for this study by Danisco SAS (Dangé St Romain, France). To minimize carryover effect, on the 
last day of periods 1,2 , and 3 , the rumen of each cow was manually emptied and the ruminal content was placed in the rumen of the next cow within the square that would receive the same treatment (Beauchemin et al., 2003).

Cows were housed in individual stalls and had free access to water and salt blocks throughout the experiment.

\section{Measurement and Sampling}

Intake and Total-Tract Digestibility. Feed intake and refusals were recorded and weighed weekly on

Table 1. Ingredient and chemical composition of the high-starch (HS) and low-starch (LS) diets used in this experiment

\begin{tabular}{lcc}
\hline Item & HS & LS \\
\hline Ingredient, \% of DM & & \\
Forages & & \\
Corn silage & 44.0 & - \\
Grass silage & - & 55.0 \\
Hay & 11.0 & - \\
Concentrates & & \\
Grain mix & 34.3 & - \\
Tanned soybean meal & 8.7 & 8.0 \\
Urea & 1.0 & - \\
Citrus pulp & - & 12.0 \\
Dehydrated beet pulp & - & 20.0 \\
Beet molasses & - & 5.0 \\
Cane molasses & 1.0 & - \\
Mineral-vitamin premix, ${ }^{2} \mathrm{~kg} / \mathrm{d}$ & 0.25 & 0.25 \\
Chemical composition, $\%$ of DM & & \\
OM & 90.3 & 88.7 \\
CP & 14.8 & 13.5 \\
NDF & 36.4 & 36.9 \\
ADF & 22.0 & 27.3 \\
Starch & 38.2 & 2.2 \\
Ether extract & 2.21 & 2.66 \\
Fatty acids (FA), g/100 g of total FA & & \\
12:0 & 0.13 & 0.16 \\
14:0 & 0.28 & 1.74 \\
16:0 & 16.2 & 19.2 \\
18:0 16:1 & 0.23 & 0.39 \\
cis-9 18:1 & 2.16 & 1.98 \\
18:2n-6 & 21.3 & 7.7 \\
Gr:3n-3 3 Noss energy, MJ/kg of DM & 47.4 & 28.3 \\
Nutritive value & 7.0 & 26.0 \\
UFL/kg of DM & 16.8 & 16.9 \\
PDIE g/kg of DM & 0.99 & 0.96 \\
PDIN g/kg of DM & 109 & 106 \\
\hline & 105 & 105 \\
\hline
\end{tabular}

${ }^{1}$ Composition (\%): barley, 14.0; wheat, 11.0; corn, 9.3.

${ }^{2}$ Minerals (\%), P (0.25), Ca (2.0), Mg (0.45), Na (0.35); trace elements $(\mathrm{mg} / \mathrm{kg}): \mathrm{Cu}(15)$; vitamins $(\mathrm{IU} / \mathrm{kg})$ : vitamin A $(6,000)$, vitamin $\mathrm{D}_{3}$ $(1,250)$, and vitamin $\mathrm{E}(10 \mathrm{mg} / \mathrm{kg})$.

${ }^{3} \mathrm{UFL}, \mathrm{PDIE}$, and PDIN are units for net energy, protein digested in the small intestine supplied by rumen undegraded dietary protein and by microbial protein from rumen fermented $\mathrm{OM}$, and protein digested in the small intestine supplied by rumen undegraded dietary protein and by microbial protein from rumen-degraded $\mathrm{N}$, respectively (INRA, 2007).
6 consecutive days in wh 3 , and on 5 consecutive days for the rest of the experiment. Dry matter contents of feed and refusals were determined on samples (200 g) taken twice a week for silages and once a week for hay and concentrates. In addition, in wk 3, daily samples of each feedstuff $(100 \mathrm{~g})$ were taken, pooled across days to provide 1 sample per period, and stored at $4^{\circ} \mathrm{C}$ (concentrates and hay) or $-20^{\circ} \mathrm{C}$ (corn and grass silages). At the end of the experiment, 1 aliquot of each sample was dried $\left(60^{\circ} \mathrm{C}\right.$ for $\left.48 \mathrm{~h}\right)$ and ground (1-mm screen) for analyses of $\mathrm{OM}, \mathrm{NDF}, \mathrm{ADF}$, nitrogen $(\mathrm{N})$, starch, ether extract, and gross energy (GE). Fatty acid composition was determined using freeze-dried and ground samples as previously described.

Total-tract digestibility was determined from total collection of feces for 6 consecutive days in wk 3 . Urine was separated from feces using a flexible pipe fixed in a pocket stuck around the vulva. Every day, after weighing and mixing, a 1\% fresh sample of feces was used for DM determination, and another $0.5 \%$ fresh portion was pooled across days by animal within each Latin square, and frozen $\left(-20^{\circ} \mathrm{C}\right)$. At the end of the experiment, pooled samples were thawed, dried $\left(60^{\circ} \mathrm{C}\right.$ for 72 $\mathrm{h}$ ), and ground (1-mm screen) to determine OM, NDF, and ADF contents.

Milk Yield and Composition. Cows were milked twice daily (0730 and $1500 \mathrm{~h}$ ) throughout the entire experiment to determine milk yield. Twice a week $(2$ nonconsecutive days), one $50-\mathrm{mL}$ aliquot from each milking was stored at $4^{\circ} \mathrm{C}$ with potassium bichromate (Merck, Fontenay-Sous-Bois, France) until analyzed for fat, protein, and lactose contents. In wk 3, additional milk samples ( $3 \mathrm{~mL}$ from morning milking and $3 \mathrm{~mL}$ from afternoon milking) were taken on 2 nonconsecutive days and stored at $-20^{\circ} \mathrm{C}$ before freeze-drying (Thermovac TM-20; Froilabo, Ozoir-la-Ferriere, France). Lyophilized milk samples collected in the morning and afternoon were then pooled (60 and $40 \mathrm{mg}$ of morning and evening samples, respectively, based on a.m. and p.m. milk production), according to Ferlay et al. (2013) to provide a daily composite sample for each cow.

Methane Emission. During the period of $6 \mathrm{~d}$ for digestibility, $\mathrm{CH}_{4}$ emission was determined using the sulfur hexafluoride $\left(\mathrm{SF}_{6}\right)$ tracer technique (Johnson et al., 1994) as previously described (Martin et al., 2008). In wk 2 of the first experimental period (i.e., $1 \mathrm{wk}$ before the first period of gas sampling), each cow was intraruminally dosed with a calibrated permeation tube of $\mathrm{SF}_{6}(1.503 \pm 0.145 \mathrm{mg} / \mathrm{d})$, which remained in the rumen throughout the experiment. Representative breath samples of each animal were collected in a preevacuated canister $(\sim 2.5 \mathrm{~L})$ by means of capillary tubing fitted to a halter. The canisters were changed every 
$24 \mathrm{~h}$ before the morning feeding. At the same time, background air gas samples were collected once daily in the barn. Daily gas samples (breath, background) were immediately transported to the laboratory for $\mathrm{SF}_{6}$ and $\mathrm{CH}_{4}$ analyses.

Ruminal Fermentation and Microbial Characteristics. On 2 nonconsecutive days in wk 4, ruminal content samples $(200 \mathrm{~g})$ were taken from the ventral sac of the rumen through the cannula, $1 \mathrm{~h}$ before and $2.5,5$, and $7 \mathrm{~h}$ after the morning feeding, and ruminal $\mathrm{pH}$ was measured immediately (pH-meter CG840, electrode $\mathrm{Ag} / \mathrm{AgCl}$, Schott Geräte, Hofheim, Germany). Samples taken before and $2.5 \mathrm{~h}$ after feeding were then subdivided for measurement of fermentation and microbial characteristics in 4 steps as follows: First, 100 $\mathrm{g}$ of ruminal content was strained through a polyester monofilament fabric $(250-\mu \mathrm{m}$ mesh aperture) and the filtrate was used for analysis of VFA, lactic acid, ammonia, and protozoa count. For VFA, a $0.8-\mathrm{mL}$ aliquot of fresh filtrate was mixed with $0.5 \mathrm{~mL}$ of $0.5 \mathrm{~N} \mathrm{HCl}$ solution containing $0.2 \%$ (wt/vol) metaphosphoric acid and $0.4 \%$ (wt/vol) crotonic acid. For ammonia- $\mathrm{N}\left(\mathrm{NH}_{3^{-}}\right.$ N), $5 \mathrm{~mL}$ of ruminal filtrate was mixed with $0.5 \mathrm{~mL}$ of $5 \% \mathrm{H}_{3} \mathrm{PO}_{4}$. The filtrates were stored at $-20^{\circ} \mathrm{C}$ until analysis. For protozoa, $3 \mathrm{~mL}$ of the fresh filtrate was mixed with $3 \mathrm{~mL}$ of methyl green-formalin-salt solution and kept at room temperature and away from light until counting. Second, $30 \mathrm{~g}$ of ruminal content was immediately washed with anaerobic buffer $(350 \mathrm{~mL}, \mathrm{pH}$ $6.5,39^{\circ} \mathrm{C}$ ) to remove the nonadherent microbial population, and washed digesta (5 g) containing the solidadherent microbial population were treated for enzyme extraction by defrosting and ultrasonic disintegration (four 30 -s periods with 30 -s intervals at $4^{\circ} \mathrm{C}$; Sonicator S-400, Misonix Inc., Farmingdale, NY) under anaerobic conditions, as detailed in Martin and Michalat-Doreau (1995). Enzyme extract was stored in capped tubes at $-80^{\circ} \mathrm{C}$ until analysis. Third, $10 \mathrm{~g}$ of ruminal content was homogenized in ice using a Polytron grinding mill (speed 5; Kinematica GmbH, Steinhofhalde, Switzerland) for two 1-min cycles with 1-min rest periods between cycles. Subsequently, 2 aliquots of $1.5 \mathrm{~g}$ were stored at $-80^{\circ} \mathrm{C}$ until DNA extraction for microbial quantification. Finally, the remaining ruminal content was dried for DM determination.

\section{Biochemical and Microbial Analyses}

Biochemical Analyses. Dry matter was measured on feed and feces after drying at $103^{\circ} \mathrm{C}$ for $24 \mathrm{~h}$, OM by ashing at $550^{\circ} \mathrm{C}$ for $6 \mathrm{~h}, \mathrm{~N}$ by the Kjeldahl procedure, starch by using the polarimetric method, and ether extract using standard procedures (AOAC International,
1997). Fiber (NDF, ADF) content was determined by sequential procedures (Van Soest et al., 1991) after pretreatment with amylase and was expressed inclusive of residual ash. The GE content was determined using an adiabatic bomb calorimeter (IKA C200, Bioritech, Guyancourt, France).

The FA composition of feed samples was determined using ground, lyophilized samples of forages and concentrates, which were methylated according to the modified method of Sukhija and Palmquist (1988) as described in Loor et al. (2004). Tricosanoate (SigmaAldrich Chimie S.a.r.l., Saint-Quentin Fallavier, France) was used as an internal standard.

The fat, protein, and lactose contents of milk were determined by infrared analysis (AOAC International, 1997) using a 3-channel spectrophotometer (CILAL, Theix, France). The FA of the lyophilized milk were methylated and analyzed according to Ferlay et al. (2013). The FAME were injected $(0.6 \mu \mathrm{L})$ by an autosampler into a gas chromatograph equipped with a flame-ionization detector (Agilent Technologies 7890A, Wilmington, DE). The FAME from all the samples were separated on a $100-\mathrm{m} \times 0.25$-mm (internal diameter) fused-silica capillary column (CP-Sil 88; Chrompack, Middelburg, the Netherlands). Peaks recorded in the chromatogram were routinely identified by retention time comparisons with commercial authentic standards containing mixtures of FAME as described earlier (Ferlay et al., 2013). The concentration of each FA was calculated from the concentration of the corresponding FAME corrected by the molecular weight.

Volatile fatty acids and lactate concentrations were determined in ruminal fluid by gas chromatography (CP 9002 Gas Chromatography, Chrompack) and an enzymatic method (Enzyplus EZA 891+, D/L-Lactic Acid, Raisio Diagnostics, Rome, Italy), respectively, as described in Lettat et al. (2010).

For $\mathrm{NH}_{3}-\mathrm{N}$, ruminal samples were centrifuged at $10,000 \times g$ for $10 \mathrm{~min}$. Ammonia $\mathrm{N}$ concentration was determined in the supernatant using the Berthelot reaction (Park et al., 2009). The reaction was carried out in duplicate in 96-well plates using an Infinity M200 spectrophotometer (Tecan Austria GmbH, Grödig, Austria).

Gas concentration $\left(\mathrm{SF}_{6}\right.$ and $\left.\mathrm{CH}_{4}\right)$ in breath and ambient air was determined using a gas chromatograph (CP-9003, Varian-Chrompack, Les Ulis, France) fitted with an electron capture detector (Autosystem XL, Perkin Elmer Instruments, Courtaboeuf, France) equipped with a Molecular Sieve 0.5-nm column $(3 \mathrm{~m} \times 3.2 \mathrm{~mm}$ i.d; Interchim, Montluçon, France) maintained at $50^{\circ} \mathrm{C}$ for $\mathrm{SF}_{6}$, or fitted with a flame-ionization detector and equipped with a Porapak N 80-100 mesh column (3 
$\mathrm{m} \times 3.2 \mathrm{~mm}$ i.d.; Alltech France SARL, Templemars, France) maintained at $40^{\circ} \mathrm{C}$ for $\mathrm{CH}_{4}$. The flow rate of the carrier gas was $30 \mathrm{~mL} / \mathrm{min}$ of $\mathrm{N}_{2}$ for $\mathrm{SF}_{6}$ and 40 $\mathrm{mL} / \mathrm{min}$ of helium for $\mathrm{CH}_{4}$. Chromatographic analyses were performed after calibration with standard gases (Air Liquide, Mitry-Mory, France) for $\mathrm{SF}_{6}$ (55 and 195 $\mathrm{pg} / \mathrm{g})$ and $\mathrm{CH}_{4}(100 \mu \mathrm{g} / \mathrm{g})$.

Microbial Analyses. Polysaccharidase activities in the solid-adherent microbial population were determined in ruminal samples by assaying the reducing sugars released from purified substrates (birchwood-xylan, Sigma X-0502; carboxymethyl cellulose, Sigma C-5678; potato starch, Sigma S-2004) after incubation for $1 \mathrm{~h}$ at $39^{\circ} \mathrm{C}$ of the enzyme extract-substrate mixture (Martin and Michalet-Doreau, 1995). The reducing sugars were converted into colored product using 4-hydroxybenzhydrazide in the presence of bismuth and quantified spectrophotometrically at $410 \mathrm{~nm}$ (Lever, 1977). The protein content of the enzyme preparations was determined according to Pierce and Suelter (1977) using BSA as standard in 96-well plates using an Infinity M200 spectrophotometer (Tecan Austria GmbH, Grödig, Austria). Finally, specific enzyme activities were expressed as micromoles of reducing sugar released per milligram of protein per hour.

For ruminal samples taken $2.5 \mathrm{~h}$ after feeding, bacteria and methanogenic Archaea concentrations were quantified by quantitative PCR as previously described (Lettat et al., 2012b, 2013). We quantified methanogenic Archaea, total bacteria, and specific bacteria that were selected based on their role in ruminal fermentation processes (i.e., starch and fiber degradation) and the utilization or production of hydrogen and lactate. The examined bacteria included Prevotella genus, which is the dominant amylolytic bacterial group and an efficient hydrogen utilizer for propionate production; the lactate-producing bacteria Lactobacillus spp. and Streptococcus bovis; the lactate-utilizing and propionate-producing bacterium Megasphaera elsdenii; the cellulolytic bacteria Fibrobacter succinogenes, a nonhydrogen-producing organism; and the hydrogenproducing bacteria Ruminococcus albus and Ruminococcus flavefaciens (Chaucheyras-Durand et al., 2010; Lettat et al., 2013). These bacteria and methanogenic Archaea were quantified using specific primers that target the 16S rrs gene, for which the sequences and amplification programs are summarized in Supplemental Tables S1 and S2 (https://doi.org/10.3168/jds.201611663) Results of enumeration are expressed as $\log _{10}$ rrs copies per gram of DM of ruminal content. Protozoa were enumerated in a Dolfuss cell (Elvetec Services, Clermont-Ferrand, France) according to the method of Jouany and Senaud (1983), and data were transformed in $\log _{10}$ cells $/ \mathrm{mL}$ of ruminal filtrate.

\section{Calculations and Statistical Analyses}

Daily $\mathrm{CH}_{4}$ production by each animal was calculated according to Lassey (2013):

$$
\begin{gathered}
\mathrm{CH}_{4}(\mathrm{~g} / \mathrm{d})=\mathrm{SF}_{6}(\mathrm{~g} / \mathrm{d}) \times\left(\left[\mathrm{CH}_{4}\right]_{\text {canister }}\right. \\
\left.-\left[\mathrm{CH}_{4}\right]_{\text {background }}\right) /\left(\left[\mathrm{SF}_{6}\right]_{\text {canister }}-\left[\mathrm{SF}_{6}\right]_{\text {background }}\right) \\
\times\left(\mathrm{MW} \mathrm{CH}_{4} / \mathrm{MW} \mathrm{SF}\right)_{6},
\end{gathered}
$$

where $\mathrm{SF}_{6}$ is known release rate of $\mathrm{SF}_{6}$ from the permeation tube; $\left[\mathrm{CH}_{4}\right]_{\text {canister }}$ and $\left[\mathrm{SF}_{6}\right]_{\text {canister }}=\mathrm{CH}_{4}$ and $\mathrm{SF}_{6}$ concentrations in the canister, respectively; $\left[\mathrm{CH}_{4}\right]_{\text {background }}$ and $\left[\mathrm{SF}_{6}\right]_{\text {background }}=$ background concentrations of $\mathrm{CH}_{4}$ and $\mathrm{SF}_{6}$, respectively; $\mathrm{MW} \mathrm{CH}_{4}$ and MW SF$F_{6}=$ molecular mass of $\mathrm{CH}_{4}(16.04 \mathrm{~g} / \mathrm{mol})$ and $\mathrm{SF}_{6}(146.06 \mathrm{~g} / \mathrm{mol})$, respectively.

For intake (6 d in wk 3$)$, milk production $(6 \mathrm{~d}$ in wk 3 ), milk composition ( $2 \mathrm{~d}$ in wh 3 ), digestibility and $\mathrm{CH}_{4}$ emission ( $6 \mathrm{~d}$ in wk 3 ), and microbial numbers ( $2 \mathrm{~d}$ in wk 4), data were averaged per period and per animal. Data of the 2 Latin squares were analyzed together using the Mixed procedure of SAS (SAS Institute Inc., Cary, NC). Intake, milk production and composition, milk FA composition, digestibility, $\mathrm{CH}_{4}$ emission, and microbial numbers were analyzed with a model including period (P; 1 to 4$)$, diet ( $\mathbf{D}$; HS and LS), DFM treatment (T; CON, P63, P63+Lp, and P63+Lr) and $\mathrm{D} \times \mathrm{T}$ interaction as fixed effects, and animal nested within diet as random effect.

Data collected at different sampling times (ruminal fermentation and microbial characteristics except microbial numbers) were analyzed with time as a repeated measure using the MIXED procedure of SAS with compound symmetric as covariance structure based on the Akaike's information criterion (Littell et al., 2000). The model included P, D, T, time $(\mathbf{t} ;-1,2.5,5$, and $7 \mathrm{~h}$ relative to feeding for $\mathrm{pH} ;-1$ and $2.5 \mathrm{~h}$ relative to feeding for fermentation and microbial characteristics, respectively), $\mathrm{T} \times \mathrm{D}, \mathrm{T} \times \mathrm{t}, \mathrm{D} \times \mathrm{t}, \mathrm{T} \times \mathrm{t} \times \mathrm{D}$ interactions as fixed effects, and animal nested within diet as random effect. Least squares means are reported with the pooled standard error of the mean derived from the model. Data were considered significant for a $P$-value $\leq 0.05$, and trends were discussed at $0.05<P \leq 0.10$.

\section{RESULTS}

\section{Intake, Milk Production, and Digestibility}

Diet and DFM treatment had no effect on DMI and milk production (Table 2). Concerning milk composition, only milk protein content tended to be higher $(P$ $=0.06)$ for the HS diet. Total-tract apparent digest- 


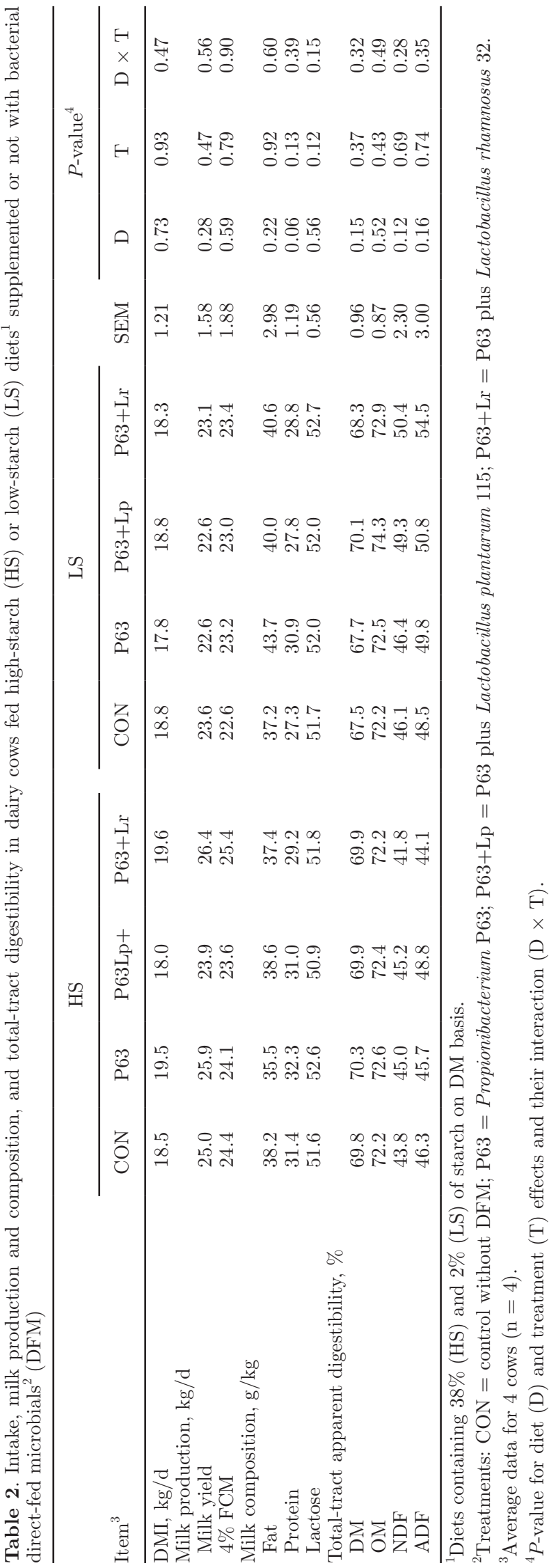

ibility of nutrients was not affected by diet or DFM treatment (Table 2).

\section{Ruminal Fermentation and Microbial Characteristics}

Diet had no effect on ruminal $\mathrm{pH}$, which had a mean value of 5.95. In contrast, ruminal $\mathrm{pH}$ was consistently higher $(P<0.01)$ with DFM supplementation compared with CON (Table 3). Total VFA concentration and proportions of acetate and butyrate were lower $(P$ $\leq 0.01)$ for the HS diet, whereas propionate $(P<0.01)$ and minor VFA $(P=0.02)$ proportions were higher. Bacterial DFM did not affect total VFA concentration or VFA pattern in the rumen. Irrespective of diet, ruminal lactate concentration was lower for the P63 treatment compared with CON $(P=0.03)$. In contrast, no effect of diet or DFM treatment was observed for $\mathrm{NH}_{3}$ concentration in the rumen.

For ruminal hydrolytic activities, microbial-associated amylase activity was higher $(P=0.03)$ for HS compared with LS, but no differences were observed for xylanase and cellulase activities according to diet (Table 4). Irrespective of diet, cellulase activity was higher $(P<0.01)$ for P63+Lr and P63+Lp compared with $\mathrm{CON}$ or P63-supplemented cows. Concentrations of total bacteria, all selected bacterial species quantified, and methanogenic Archaea were higher $(P \leq 0.04)$ for the HS compared with the LS diet, whereas protozoa counts were lower $(P<0.01)$. In contrast, DFM supplementation did not affect the concentration of the microbes monitored.

\section{Enteric Methane Emission}

As expected based on differences in starch concentration between diets, $\mathrm{CH}_{4}$ emission in cows fed the HS diet was about one-third less $(P<0.05)$ than that observed in cows fed the LS diet (Table 4). Bacterial DFM supplementation of the HS diet did not affect $(P>0.05) \mathrm{CH}_{4}$ emission. However, supplementation with $\mathrm{P} 63+\mathrm{Lr}$ on the LS diet tended to decrease $\mathrm{CH}_{4}$ emission by $26 \%$, on average, when expressed as grams per kilogram of milk or grams per kilogram of $4 \%$ FCM $(0.08 \geq P \geq 0.10$; Table 5).

\section{Milk FA Composition}

Milk concentrations of individual odd-chain FA (9:0, 11:0) were higher $(P=0.02)$ for the HS diet than for the LS diet, whereas concentrations of branched-chain FA (13:0 iso, 14:0 iso, 15:0 iso, and 15:0 anteiso) were lower $(P<0.05$; Table 6 and Supplemental Table S3; https://doi.org/10.3168/jds.2016-11663) Milk concentrations of individual cis (cis-11 and cis-13) and trans 
(from trans- 4 to trans-9 and trans-12) isomers of 18:1 and the trans-10 to trans-11 ratio were higher $(P<0.05)$ for the HS diet, whereas cis-14 18:1 concentration was lower $(P=0.02)$ for the HS diet (Table 6; Supplemental Table S3). The proportions in milk FA of total PUFA, 18:2n-6, long-chain n-6 FA (20:4n-6, 22:4n-6), and total n-6 FA were higher $(P<0.05)$, whereas total n-3 FA and individual n-3 FA (18:3n-3, 20:5n-3 and 22:5n-3) concentrations were lower $(P<0.01)$ than with the LS diet (Table 6; Supplemental Table S3). Moreover, saturated long-chain FA (18:0, 20:0, 22:0) and cis-9,cis-11 CLA and trans-11,trans-13 CLA concentrations were lower $(P \leq 0.01)$ with the HS diet than with the LS diet (Table 6; Supplemental Table S3).

The DFM treatment had less effect on milk FA concentrations. Irrespective of diet, the proportion of cis-9 16:1 in milk FA tended $(P=0.07)$ to be the highest for P63 supplementation (Table 6). For some milk FA, interactions between treatment and diet were found. Compared with the CON treatment of the HS diet, P63 supplementation of HS diet induced higher concentrations of cis-12 $(P=0.04)$ and cis-15 $(P=0.05)$ isomers of 18:1 and tended to have higher concentrations of 17:0 $(P=0.07)$, cis-9 17:1 $(P=0.08)$, cis-9, trans-11 CLA $(P=0.08)$, and total CLA $(P=0.10)$, whereas milk concentrations of 14:0 $(P=0.06)$ and total SFA $(P=0.10)$ tended to be the lowest with P63 supplementation of HS diet (Table 6).

\section{DISCUSSION}

\section{DFM and Ruminal Characteristics}

The aim of the present study was to assess the effects of DFM supplementation in dairy cows receiving diets differing in the nature of their carbohydrates to induce different ruminal VFA profiles. For the HS diet, the VFA profile was characterized by a high proportion of propionate, which was consistent with the greatest specific amylase activity and concentrations of total bacteria, Megasphaera elsdenii, Prevotella spp., and $S$. bovis. In contrast, for the LS diet, the ruminal fermentation pattern was characterized by high proportions of acetate and butyrate, which can be explained by a high amount of soluble carbohydrates provided by some feed ingredients such as dehydrated beet pulp, molasses, and citrus pulp in substitution of grain mix (Lean et al., 2014). More specifically, the high butyrate proportion may be related to the high concentration of protozoa, which was in agreement with previous experimental data on sheep (Williams and Coleman, 1992; Brossard et al., 2004).

Our study provides original data on the effect of bacterial DFM supplementation in dairy cows. Irrespective 
PHILIPPEAU ET AL.

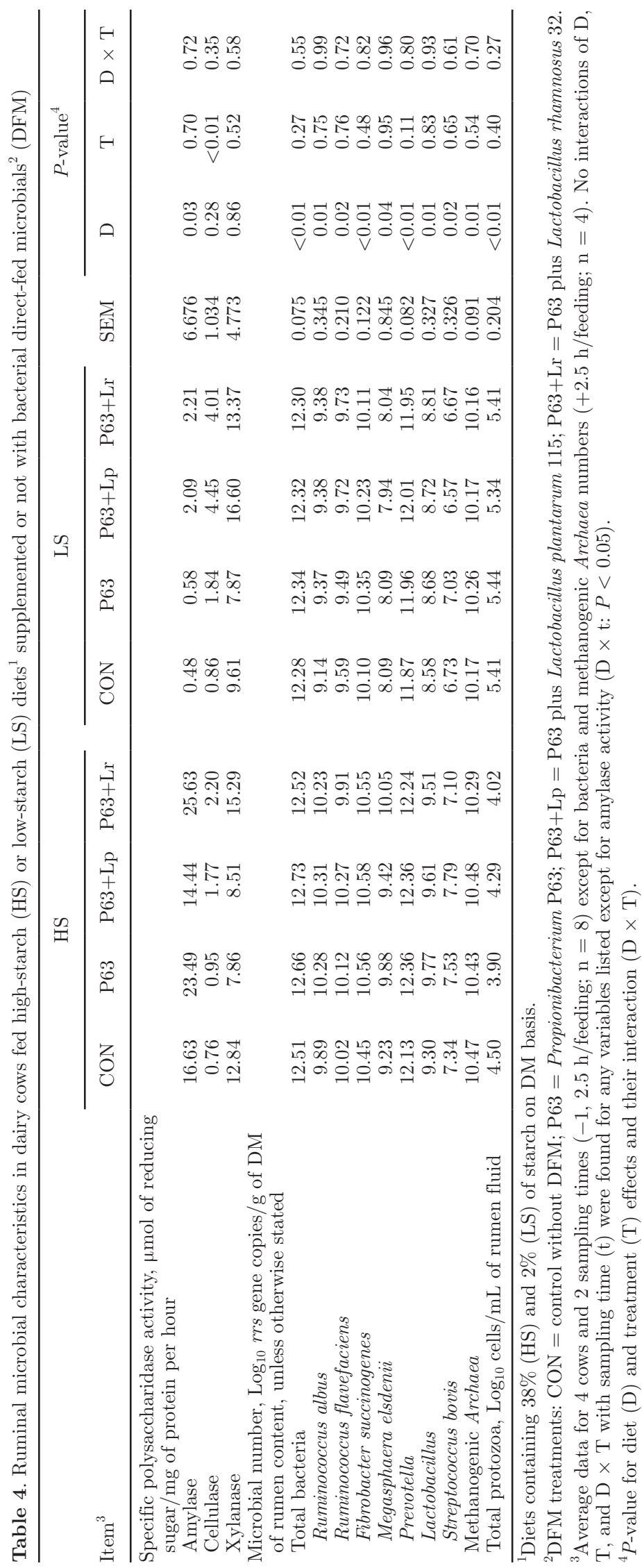


of diet, all bacterial DFM induced an average increase of 0.18 units in mean ruminal $\mathrm{pH}$. No previous studies have reported a significant effect of bacterial DFM on ruminal $\mathrm{pH}$ in dairy cows. In beef steers, Kenney et al. (2015) reported an increase in mean ruminal $\mathrm{pH}$ after 28-d supplementation with bacterial DFM containing Lactobacillus acidophilus and Enterococcus faecium. In a meta-analysis ( $\mathrm{n}=13$ experiments) based on trials in dairy cows and beef steers, no significant effect of bacterial DFM supplementation on ruminal $\mathrm{pH}$ was reported (Lettat et al., 2012a). In contrast, particularly at suboptimal ruminal $\mathrm{pH}$ values, combinations of $E$. faecium and $S$. cerevisiae had a marked modulatory effect on ruminal pH (Chiquette, 2009; Lettat et al., 2012a). In the present study, the higher $\mathrm{pH}$ value with DFM supplementation could not be easily explained by alterations of ruminal fermentation characteristics. It could not be attributed to decrease in concentrations of measured organic acids (VFA, lactate) or an increase in ruminal buffer $\left(\mathrm{NH}_{3}\right)$. Other factors may be proposed such as differences in the buffering capacity of saliva, the ruminal dissolved $\mathrm{CO}_{2}$ concentration, the absorption of organic acids through the rumen wall, and the passage to the lower digestive tract (Allen, 1997; Laporte-Uribe, 2016). However, these variables were not measured in this study.

Consistent with this result, no effect of bacterial DFM on total VFA concentration was found in a metaanalysis based on beef steers and dairy cows $(n=9$ experiments; Lettat et al., 2012a). Irrespective of diet, the P63 treatment led to a decrease in lactate concentration compared with the control diet. However, the effect on ruminal $\mathrm{pH}$ is not considered important because the concentration of lactate in diets not supplemented with P63 was low. Irrespective of diet, bacterial DFM supplementation did not induce changes in ruminal VFA profiles. Similarly, no variation in VFA profiles was reported with different strains of Propionibacterium supplemented to beef cattle fed a high-forage diet (Vyas et al., 2014a) or a corn grain finishing diet (Vyas et al., 2014b). More recently, beef steers fed a corn-based finishing diet supplemented with lactateproducing bacterial DFM, Lactobacillus acidophilus and Enterococcus faecium, showed a slight increase in acetate proportion (Kenney et al., 2015).

Few studies have investigated the effect of bacterial DFM in contrasted feeding situations. Our results do not support the hypothesis postulating that the effectiveness of bacterial DFM on ruminal characteristics was conditioned by ruminal VFA profiles. In a previous study investigating the effect of bacterial DFM in wethers fed diets containing wheat, corn, or beet pulp as the main energy source, Lettat et al. (2012b) found that P63 supplementation tended to increase acetate pro- 


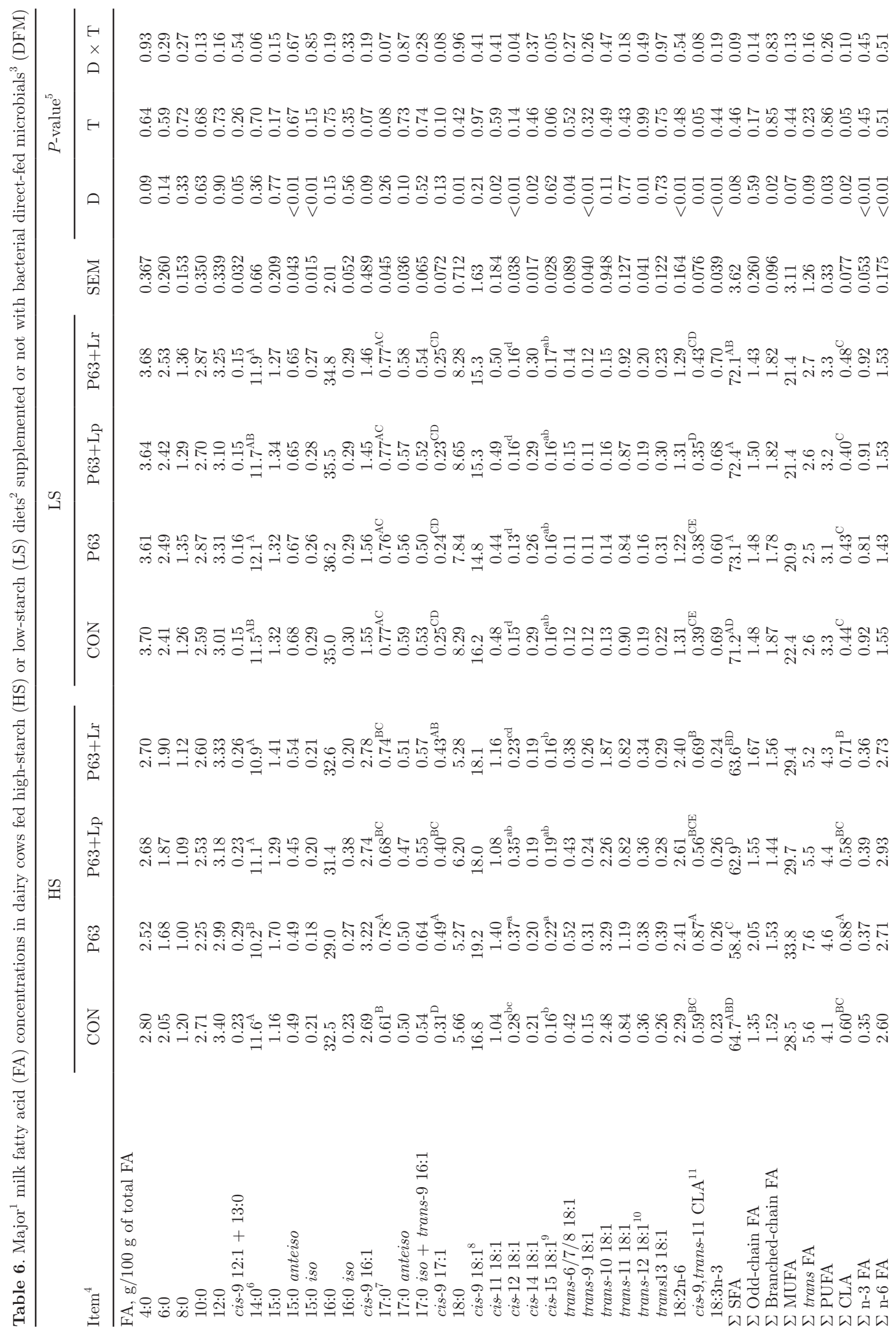




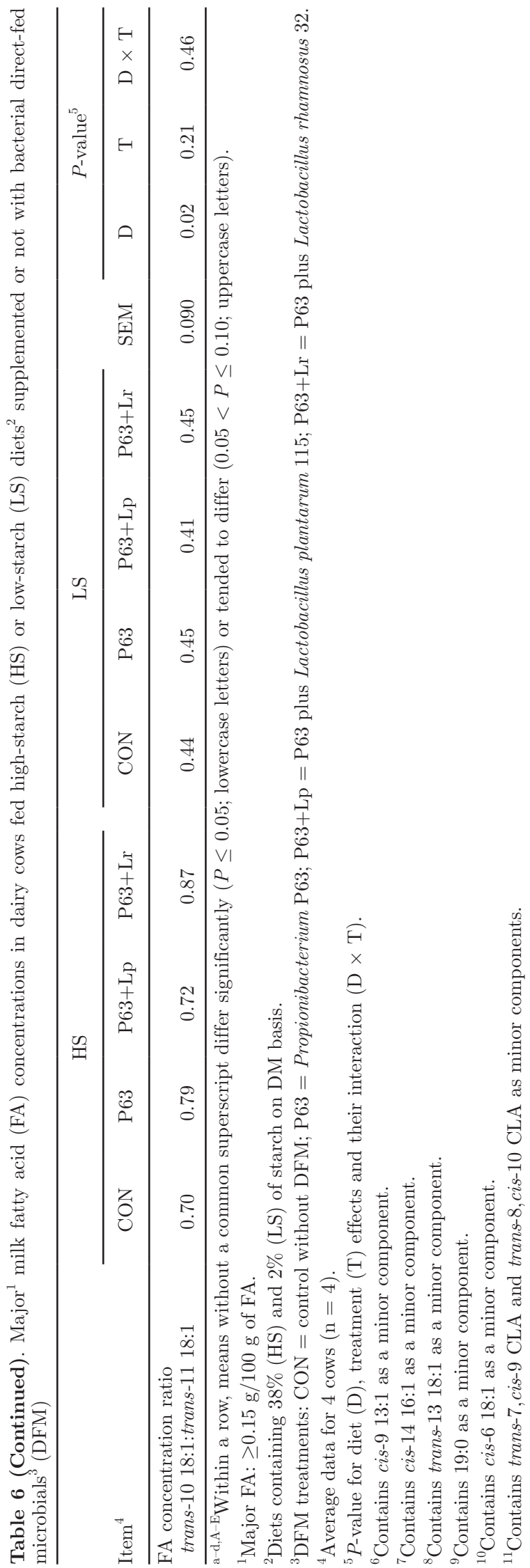

portion and to decrease propionate proportion, whereas P63+Lp increased acetate proportion in wethers fed the corn diet. In a meta-analysis based on beef steers and dairy cows ( $\mathrm{n}=14$ experiments), DFM supplementation decreased acetate proportion, and this variation was more marked when bacterial DFM were associated with S. cerevisiae (Lettat et al., 2012a).

Similarly, bacterial DFM did not modify bacterial composition or concentrations of methanogenic Archaea and protozoa. In the literature, few reports have described the effect of bacterial DFM on selected ruminal microbes. In steers, Propionibacterium P15 supplementation decreased amylolytic bacteria count and increased protozoa number (Ghorbani et al., 2002). A tendency to decreased concentration of protozoa following E. faecium supplementation was reported in steers (Beauchemin et al., 2003). In wethers fed a corn diet, P63+Lp decreased Prevotella spp. (Lettat et al., 2012b). Only lactobacilli associated with P63 increased cellulase activity in the present study, which did not result in an improvement in NDF digestibility in the total tract. As the relationship between fibrolytic activity and degradation of fiber in the rumen is not linear (Nozière et al., 1996; Martin et al., 2002), we can suppose that the cellulolytic activity was not limiting for ruminal fiber degradation under our conditions. In addition, the potential changes in ruminal fiber degradation may have been too low to be perceptible at the whole-tract digestibility level.

\section{DFM and Methane Emission}

Most methanogenic Archaea use $\mathrm{H}_{2}$ to reduce $\mathrm{CO}_{2}$ into $\mathrm{CH}_{4}$. Because $\mathrm{CO}_{2}$ is not a limiting substrate of rumen methanogenesis, $\mathrm{CH}_{4}$ emission is mainly linked to production of $\mathrm{H}_{2}$, a by-product of organic matter ruminal degradation (Morgavi et al., 2010). Thus, diets rich in starch (such as the HS diet) favor propionic production in the rumen, which is an $\mathrm{H}_{2}$-consuming pathway, whereas the LS diet favored acetic and butyric production, which generates $\mathrm{H}_{2}$ (Martin et al., 2010). In the present study, irrespective of the expression unit, cows fed the HS diet produced effectively less $\mathrm{CH}_{4}$ than cows on the LS diet, in agreement with previous data comparing diets differing in concentrations of starch and fibrous constituents (Beauchemin and McGinn, 2005; Martin et al., 2010; Hassanat et al., 2013).

The use of bacterial DFM has been hypothesized to reduce $\mathrm{CH}_{4}$ emission by altering ruminal fermentation patterns (Jeyanathan et al., 2014). Irrespective of diet, Propionibacterium $\mathrm{P} 63$ did not affect $\mathrm{CH}_{4}$ emission compared with the control treatment. Likewise, $\mathrm{CH}_{4}$ emission $(\mathrm{g} / \mathrm{d})$ was not affected by different strains of Propionibacterium in beef cattle fed a corn grain fin- 
ishing diet (Vyas et al., 2014b), whereas these strains induced a slight decrease in $\mathrm{CH}_{4}$ emission (on average, $-13 \% \mathrm{CH}_{4}$ expressed per $\mathrm{kg}$ of DMI) when they were fed a high-forage diet (Vyas et al., 2014a). For the latter studies, the lack of effect on methanogenesis was correlated with no changes in ruminal fermentation characteristics (Vyas et al., 2014a,b). Those authors suggested that the limited effect of the selected Propionibacterium species on ruminal metabolism and $\mathrm{CH}_{4}$ emission was related to the inability of these bacteria to persist in this digestive fermentor. More recently, Jeyanathan et al. (2016) showed a great variability in the 24-h survival rate between strains of propionibacteria and lactobacilli, which may affect the amplitude of their effect on $\mathrm{CH}_{4}$ emission and microbial characteristics. Collectively, these data support the requirement of daily supplementation with DFM for modulating ruminal traits of interest.

When P63 were combined with $\mathrm{Lr}, \mathrm{CH}_{4}$ emission, expressed per kilogram of milk or $4 \%$ FCM, tended to decrease ( $26 \%$ on average) for cows fed the LS diet and reached a level of production comparable to that of the HS diet. For this treatment, the $\mathrm{CH}_{4}$-mitigating effect was not related to variation in ruminal fermentation or microbial characteristics. This result is inconsistent with the positive relation established between $\mathrm{CH}_{4}$ and protozoa (Guyader et al., 2014) but agrees with Morgavi et al. (2010), who reported no consistent relation between $\mathrm{CH}_{4}$ emission and concentration of methanogenic Archaea. The reduction in methane output may be due to lower archaeal activity or to a shift in archaeal community structure toward less efficient $\mathrm{CH}_{4}$-producing species (Popova et al., 2011; Lettat et al., 2013). In line with the existing reports, the mode of action of the administered bacterial DFM in modulating microbial community is unclear. However, in vitro, some strains of Propionibacterium and Lactobacillus spp. can produce antimicrobial peptides such as bacteriocins that affect $\mathrm{CH}_{4}$ production (Jeyanathan et al., 2014). Based on investigations in monogastric animals and preruminant calves, several other mechanisms have been proposed, such as competition with the undesirable organisms for adhesion sites or nutrients, metabolism and detoxification of toxins, and production or stimulation of enzyme secretion (Azzaz et al., 2016).

\section{DFM and Milk FA Composition}

As expected, high variations in milk n- 6 and n-3 FA concentrations between the 2 diets reflected differences in FA composition of both concentrate and forage types (Chilliard and Ferlay, 2004; Chilliard et al., 2007). The higher concentrations of milk odd-chain SFA (9:0 and 11:0) with the HS diet could be explained by the en- hanced ruminal production of propionate, which is used by the mammary gland to synthesize these FA (Bernard et al., 2008). Moreover, cows fed the HS diet produced milk fat characterized by lower branched-chain FA (Fievez et al., 2012) and 18:0 concentrations and higher trans isomers of 18:1 (Enjalbert et al., 2008). In these previous studies, the variations in milk FA composition were usually observed with acidogenic diets rich in starch and were attributed to modification of ruminal fermentation and biohydrogenation pathways. In the present study, differences in milk FA composition between the HS and LS diets may be attributed mainly to a marked difference in starch content $(36 \%)$ because no significant variation in ruminal $\mathrm{pH}$ was reported. This result confirms that milk FA profiles may differ according to the acidotic feeding strategy (Colman et al., 2013).

In agreement with previous results obtained with other DFM such as S. cerevisiae (Longuski et al., 2009; Hristov et al., 2010; Bayat et al., 2015), bacterial DFM supplementation slightly modified the milk FA profile irrespective of the diet. However, P63 supplementation modified concentrations of some milk cis-isomers of 18:1 and intermediates of ruminal biohydrogenation of PUFA. The variations in the concentration of these latter FA could be related to alterations in the ruminal microbial ecosystem. The effect of bacterial DFM on the main biohydrogenating microbes present in the rumen should be further explored in specifically designed experiments.

\section{CONCLUSIONS}

In dairy cows, DFM containing Propionibacterium P63 alone or in association with Lactobacillus plantarum 115 or Lactobacillus rhamnosus 32 effectively increased ruminal $\mathrm{pH}$ irrespective of diet. Although these bacterial DFM did not affect ruminal VFA profile, their effectiveness on methane emission and milk FA composition depended on the ruminal fermentation pattern induced by diet. Methane emission decreased in cows fed a low-starch diet supplemented with a combination of Propionibacterium P63 and Lactobacillus rhamnosus 32. Supplementing cows fed a high-starch diet with Propionibacterium P63 slightly modified the milk FA profile. These results deserve further confirmation and explanation of the potential mechanisms of action of bacterial DFM supplementation in diets of dairy cows before we can recommend their use.

\section{ACKNOWLEDGMENTS}

A. Lettat was the recipient of a CIFRE Danisco SAS research fellowship. The authors thank D. Bany, 
L. Genestoux, Y. Rochette, and E. Tixier (UMR1213 Herbivores) for laboratory analyses, and L. Mouly, B. Robert, D. Roux, and S. Rudel (UE1414 Herbipole, Saint-Genes Champanelle, France) for animal care. Special thanks go to M. Fabre for protozoa counting and the pleasant memories he left his colleagues. We are also grateful to P. Mosoni and F. Chaucheyras-Durand (UR454 Microbiologie) and P. Horvath (Danisco, SAS France) for providing the rrs standards used here.

\section{REFERENCES}

Alazzeh, A. Y., H. Sultana, K. A. Beauchemin, Y. Wang, H. Holo, O. M. Harstad, and T. A. McAllister. 2012. Using strains of Propionibacteria to mitigate methane emissions in vitro. Acta Agric. Scand. 62:263-272.

Allen, M. S. 1997. Relationship between fermentation acid production in the rumen and the requirement for physically effective fiber. J. Dairy Sci. 80:1447-1462.

AOAC International. 1997. Official Methods of Analysis. 16th ed. AOAC International, Gaithersburg, MD.

Azzaz, H. H., T. A. Morsy, and H. A. Murad. 2016. Microbial feed supplements for ruminant's performance enhancement. Asian J. Agric. Res. 10:1-14.

Bayat, A. R., P. Kairenius, T. Stefanski, H. Leskinen, S. ComtetMarre, E. Forano, F. Chaucheyras-Durand, and K. J. Shingfield. 2015. Effect of camelina oil or live yeasts (Saccharomyces cerevisiae) on ruminal methane production, rumen fermentation, and milk fatty acid composition in lactating cows fed grass silage diets. J. Dairy Sci. 98:3166-3181.

Beauchemin, K. A., and S. M. McGinn. 2005. Methane emissions from feedlot cattle fed barley or corn diets. J. Anim. Sci. 83:653-661.

Beauchemin, K. A., W. Z. Yang, D. P. Morgavi, G. R. Ghorbani, W. Kautz, and J. A. Z. Leedle. 2003. Effects of bacterial direct-fed microbials and yeast on site and extent of digestion, blood chemistry, and subclinical ruminal acidosis in feedlot cattle. J. Anim. Sci. 81:1628-1640.

Bernard, L., C. Leroux, and Y. Chilliard. 2008. Expression and nutritional regulation of lipogenic genes in the ruminant lactating mammary gland. Adv. Exp. Med. Biol. 606:67-108.

Brossard, L., C. Martin, F. Chaucheyras-Durand, and B. MichaletDoreau. 2004. Protozoa involved in butyric rather than lactic fermentative pattern during latent acidosis in sheep. Reprod. Nutr. Dev. 44:195-206.

Chaucheyras-Durand, F., S. Masséglia, G. Fonty, and E. Forano. 2010. Influence of the composition of the cellulolytic flora on the development of hydrogenotrophic microorganisms, hydrogen utilization, and methane production in the rumens of gnotobiotically reared lambs. Appl. Environ. Microbiol. 76:7931-7937.

Chaucheyras-Durand, F., N. D. Walker, and A. Bach. 2008. Effects of active dry yeasts on the rumen microbial ecosystem: Past, present and future. Anim. Feed Sci. Technol. 145:5-26.

Chilliard, Y., and A. Ferlay. 2004. Dietary lipids and forages interactions on cow and goat milk fatty acid composition and sensory properties. Reprod. Nutr. Dev. 44:467-492.

Chilliard, Y., F. Glasser, A. Ferlay, L. Bernard, J. Rouel, and M. Doreau. 2007. Diet, rumen biohydrogenation and nutritional quality of cow and goat milk fat. Eur. J. Lipid Sci. Technol. 109:828855 .

Chiquette, J. 2009. Evaluation of the protective effect of DFM fed to dairy cows during a subacute ruminal acidosis challenge. Anim. Feed Sci. Technol. 153:278-291.

Colman, E., E. Khafipour, B. Vlaeminck, B. De Baets, J. C. Plaizier, and V. Fievez. 2013. Grain-based versus alfalfa-based subacute ruminal acidosis induction experiments: Similarities and differences between changes in milk fatty acids. J. Dairy Sci. 96:4100-4111.
Desnoyers, M., S. Giger-Reverdin, G. Bertin, C. Duvaux-Ponter, and D. Sauvant. 2009. Meta-analysis of the influence of Saccharomyces cerevisiae supplementation on ruminal parameters and milk production of ruminants. J. Dairy Sci. 92:1620-1632.

Enjalbert, F., Y. Videau, M. C. Nicot, and A. Troegeler-Meynadier. 2008. Effects of induced subacute ruminal acidosis on milk fat content and milk fatty acid profile. J. Anim. Physiol. Anim. Nutr. (Berl.) 92:284-291.

Ferlay, A., M. Doreau, C. Martin, and Y. Chilliard. 2013. Effects of incremental amounts of extruded linseed on the milk fatty acid composition of dairy cows receiving hay and corn silage. J. Dairy Sci. 96:6577-6595.

Fievez, V., E. Colman, J. M. Castro-Montoya, I. Stefanov, and B. Vlaeminck. 2012. Milk odd- and branched-chain fatty acids as biomarkers of rumen function-An update. Anim. Feed Sci. Technol. 172:51-65.

Ghorbani, G. R., D. P. Morgavi, K. A. Beauchemin, and J. A. Leedle. 2002. Effects of bacterial direct-fed microbials on ruminal fermentation, blood variables, and the microbial populations of feedlot cattle. J. Anim. Sci. 80:1977-1985.

Guyader, J., M. Eugène, P. Nozière, D. P. Morgavi, M. Doreau, and C. Martin. 2014. Influence of rumen protozoa on methane emissions in ruminants: A meta-analysis approach. Animal 8:1816-1825.

Hassanat, F., R. Gervais, C. Julien, D. I. Massé, A. Lettat, P. Y. Chouinard, H. V. Petit, and C. Benchaar. 2013. Replacing alfalfa silage with corn silage in dairy cow diets: Effects on enteric methane production, ruminal fermentation, digestion, $\mathrm{N}$ balance, and milk production. J. Dairy Sci. 96:4553-4567.

Hennessy, A. A., E. Barrett, R. P. Ross, G. F. Fitzgerald, R. Devery, and C. Stanton. 2012. The production of conjugated $\alpha$-linolenic, $\gamma$-linolenic and stearidonic acids by strains of Bifidobacteria and Propionibacteria. Lipids 47:313-327.

Hristov, A. N., G. Varga, T. Cassidy, M. Long, K. Heylar, S. K. R. Karnati, B. Corl, C. J. Hovde, and I. Yoon. 2010. Effect of Saccharomyces cerevisiae fermentation product on ruminal fermentation and nutrient utilization in dairy cows. J. Dairy Sci. 93:682-692.

INRA (Institut National de la Recherche Agronomique). 2007. Alimentation des bovins, ovins et caprins-Besoins des animaux-Valeurs des aliments Tables INRA 2007. Editions Quae, Versailles, France.

Jeyanathan, J., C. Martin, and D. P. Morgavi. 2014. The use of directfed microbials for mitigation of ruminant methane emisions: a review. Animal 8:250-261.

Jeyanathan, J., C. Martin, and D. P. Morgavi. 2016. Screening of bacterial direct-fed microbials for their antimethanogenic potential in vitro and assessment of their effect on ruminal fermentation and microbial profiles in sheep. J. Anim. Sci. 94:739-750.

Johnson, K., M. Huyler, H. Westberg, B. Lamb, and P. Zimmerman. 1994. Measurement of methane emissions from ruminant livestock using a sulfur hexafluoride tracer technique. Environ. Sci. Technol. 28:359-362.

Jouany, J. P., and J. Senaud. 1983. Influence des ciliés du rumen sur l'utilisation digestive de différents régimes riches en glucides solubles et sur les produits terminaux formés dans le rumen. Il.Régimes contenant de l'inuline, du saccharose et du lactose. Reprod. Nutr. Dev. 23:607-623.

Kenney, N. M., E. S. Vanzant, D. L. Harmon, and K. R. McLeod. 2015. Direct-fed microbials containing lactate-producing bacteria influence ruminal fermentation but not lactate utilization in steers fed a high-concentrate diet. J. Anim. Sci. 93:2336-2348.

Laporte-Uribe, J. A. 2016. The role of dissolved carbon dioxide in both the decline in rumen $\mathrm{pH}$ and nutritional diseases in ruminants. Anim. Feed Sci. Technol. 219:268-279.

Lassey, K. R. 2013. On the importance of background sampling in applications of the $\mathrm{SF}_{6}$ tracer technique to determine ruminant methane emissions. Anim. Feed Sci. Technol. 180:115-120.

Lean, I. J., H. M. Golder, and M. B. Hall. 2014. Feeding, evaluating, and controlling rumen function. Vet. Clin. North Am. Food Anim. Pract. 30:539-575.

Lettat, A., F. Hassanat, and C. Benchaar. 2013. Corn silage in dairy cow diets to reduce ruminal methanogenesis: Effects on the ru- 
men metabolically active microbial communities. J. Dairy Sci. 96:5237-5248.

Lettat, A., C. Martin, C. Berger, and P. Noziere. 2012a. Analyse quantitative de l'effet des bactéries probiotiques sur les fermentations dans le rumen et les performances des bovins en production. INRA Prod. Anim. 25:351-360.

Lettat, A., P. Noziere, M. Silberberg, D. Morgavi, C. Berger, and C. Martin. 2010. Experimental feed-induction of lactic, propionic and butyric acidosis in sheep. J. Anim. Sci. 88:3041-3046.

Lettat, A., P. Noziere, M. Silberberg, D. Morgavi, C. Berger, and C. Martin. 2012b. Rumen microbial and fermentation characteristics are affected differently by bacterial probiotic supplementation during induced lactic and subacute acidosis in sheep. BMC Microbiol. $12: 142-154$.

Lever, M. 1977. Carbohydrate determination with 4-hydroxybenzoic acid hydrazide (PAHBAH): Effect of bismuth on the reaction. Anal. Biochem. 81:21-27.

Littell, R. C., J. Pendergast, and R. Natarajan. 2000. Modelling covariance structure in the analysis of repeated measures data. Stat. Med. 19:1793-1819.

Longuski, R. A., Y. Ying, and M. S. Allen. 2009. Yeast culture supplementation prevented milk fat depression by a short-term dietary challenge with fermentable starch. J. Dairy Sci. 92:160-167.

Loor, J. J., K. Ueda, A. Ferlay, Y. Chilliard, and M. Doreau. 2004. Biohydrogenation, duodenal flow, and intestinal digestibility of trans fatty acids and conjugated linoleic acids (CLA), in response to dietary forage:concentrate ratio and linseed oil in dairy cows. J. Dairy Sci. 87:2472-2485.

Martin, C., G. Fonty, and B. Michalet-Doreau. 2002. Factors affecting the fibrolytic activity of the digestive microbial ecosystems in ruminants. Pages 1-17 in Gastrointestinal Microbiology in Animals. S. A. Martin, ed. Research Signpost, Trivandrum, India.

Martin, C., and B. Michalet-Doreau. 1995. Variations in mass and enzyme activity of rumen microorganisms: Effect of barley and buffer supplements. J. Sci. Food Agric. 67:407-413.

Martin, C., D. P. Morgavi, and M. Doreau. 2010. Methane mitigation in ruminants: from microbe to the farm scale. Animal 4:351-365.

Martin, C., J. Rouel, J. P. Jouany, M. Doreau, and Y. Chilliard. 2008 Methane output and diet digestibility in response to feeding dairy cows crude linseed, extruded linseed, or linseed oil. J. Anim. Sci. $86: 2642-2650$

McAllister, T. A., K. A. Beauchemin, A. Y. Allazeh, J. Baah, R. M. Teather, and K. Standford. 2011. Review: The use of direct fed microbials to mitigate pathogens and enhance prodiction in cattle. Can. J. Anim. Sci. 91:1-19.

Meale, S. J., S. Ding, M. L. He, M. E. R. Dugan, G. O. Ribeiro Jr., A. Y. Alazzeh, H. Holo, O. M. Harstad, T. A. McAllister, and A. V. Chaves. 2014. Effect of Propionibacterium freudenreichii on ruminal fermentation patterns, methane production and lipid biohydrogenation of beef finishing diets containing flaxseed oil in a rumen simulation technique. Can. J. Anim. Sci. 94:685-695.

Morgavi, D. P., E. Forano, C. Martin, and C. J. Newbold. 2010 Microbial ecosystem and methanogenesis in ruminants. Animal 4:1024-1036.

Nozière, P., J. M. Besle, C. Martin, and B. Michalet-Doreau. 1996. Effect of barley supplement on microbial fibrolytic enzyme activities and cell-wall degradation rate in the rumen. J. Sci. Food Agric. $72: 235-242$.

Park, G., H. Oh, and S. Ahn. 2009. Improvement of the ammonia analysis by the phenate method in water and wastewater. Bull. Korean Chem. Soc. 30:2032-2038.

Pierce, J., and C. H. Suelter. 1977. An evaluation of the Coomassie brilliant blue G-250 dye-binding method for quantitative protein determination. Anal. Biochem. 81:478-480.

Popova, M., C. Martin, M. Eugène, M. Mialon, M. Doreau, and D. P. Morgavi. 2011. Effect of fibre-and starch-rich finishing diets on methanogenic Archaea diversity and activity in the rumen of feedlot bulls. Anim. Feed Sci. Technol. 166:113-121.

Sukhija, P. S., and D. L. Palmquist. 1988. Rapid method for determination of total fatty acid content and composition of feedstuffs and feces. J. Agric. Food Chem. 36:1202-1206.

Van Soest, P. J., J. B. Robertson, and B. A. Lewis. 1991. Methods for dietary fiber, neutral detergent fiber, and nonstarch polysaccharides in relation to animal nutrition. J. Dairy Sci. 74:3583-3597.

Vyas, D., E. J. McGeough, S. M. McGinn, T. A. McAllister, and K. A Beauchemin. 2014a. Effect of Propionibacterium spp. on ruminal fermentation, nutrient digestibility, and methane emissions in beef heifers fed a high-forage diet. J. Anim. Sci. 92:2192-2201.

Vyas, D., E. J. McGeough, R. Mohammed, S. M. McGinn, T. A. McAllister, and K. A. Beauchemin. 2014b. Effects of Propionibacterium strains on ruminal fermentation, nutrient digestibility and methane emissions in beef cattle fed a corn grain finishing diet. Animal 8:1807-1815.

Williams, A. G., and G. S. Coleman. 1992. The Rumen Protozoa. Springer-Verlag, New York, NY. 